\title{
Experiences of an automatic small-scale 'home bakery' in test bakings of six spring wheat varieties
}

\author{
JARI PELTONEN* and HANNU SALOVAARA** \\ * Department of Crop Husbandry and \\ ** Department of Food Chemistry and Technology \\ SF-00710 Helsinki, Finland
}

\begin{abstract}
Four units of an automatic small-scale 'home bakery' (Panasonic SD-BT2P, Japan) were tested for their suitability for rapid and simplified test baking. The results indicated that the four baking machines used produced loaves equal in volume. Loaf volume increased with increasing values of protein content, wet gluten content, sedimentation value, and with farinograph dough development time and stability values. Varietal differences in the relationship between quality and loaf volume were detected.
\end{abstract}

Index words: small-scale test baking, home bakery, wheat flour, baking quality

\section{Introduction}

Test baking is recognized as the final analytical tool in the evaluation of wheat and flour quality. However, test baking is a laborious procedure, and often constitutes a bottleneck in studies of the baking quality of wheat lots. In 1987 Japanese small-scale automatic 'home-bakeries' were brought onto the market for use in household bread baking. Since then there has been an interest in these apparatuses also in cereal laboratories, and questions have been raised as to whether the automatic home-bakeries could be of use in professional test baking.

To be successful a baking test must produce repeatable results. The results must also be accurate, i.e. the precision of the test must be high enough for even slight differences in baking performance to be detected. Furthermore the results should be reliable and show concordance with other quality parameters, especially with industrial baking performance.

One approach in test baking may be that of material testing, i.e. detection of weakness or incompleteness in the material and discrimination of materials not meeting the required standards or specifications. Another approach in test baking would be an optimized test baking procedure, in which the processing 
parameters are adjusted or optimized according to the properties of the flour. The current test baking procedures normally are compromises of the two approaches.

It is apparent that the automatic bread baking units used in the present study (Panasonic SD-BT2P) or corresponding equipment manufactured by other companies will have been tested for test baking purposes in many laboratories. However, very few studies have been published. ZawitowsKA et al. (1988) used the Panasonic SD-BT2P unit in a study which showed the effects of excessive alphaamylase activity on the properties of bread crumbs. Svensson and Peltonen (1991) used a similar unit in their study of water absorption and gluten quality of wheat flour in a breeding material. Some flour mills in Ger-

Table 1. Baking formula.

\begin{tabular}{lr}
\hline Flour & $300.0 \mathrm{~g}$ \\
Bakery margarine (Vaasan Leivonen Ltd.) & $9.0 \mathrm{~g}$ \\
Saccharose & $6.0 \mathrm{~g}$ \\
Salt & $3.0 \mathrm{~g}$ \\
Ascorbic acid, AA & $0.01 \mathrm{~g}$ \\
Instant active dry yeast (IADY) & $3.0 \mathrm{~g}$ \\
Water & $200 \mathrm{ml}$ \\
\hline * Added separately, (Fermipan, Gist-Brocades) \\
** Adjusted acc. to water absorption
\end{tabular}

many have used modified units of the homebakery for quality control of wheat flour (Seibel 1988, Personal communication).

The purpose of the present study was to show whether the loaf volumes obtained with four units of Panasonic SD-BT2P were repeatable and whether the loaf volumes correlated with varying protein contents or other quality parameters in a test material consisting of six spring wheat cultivars.

\section{Materials and Methods}

The test materials available for the study were flours from six Finnish grown spring wheat cultivars (Reno, Luja, Ruso, Kadett, Drabant, and Tapio), each at five protein levels. The analytical data of the composite wheat lots used for baking test was obtained from SalovaAra (1989). A regular commercial white wheat flour was used as a reference.

Four units of Panasonic SD-BT2P 'homebakeries' were used in the study. All the ingredients - except yeast - were added simultaneously to the combined mixing-fermentation-baking pan (Table 1). Loaf volumes were determined by the rapeseed displacement method. All baking tests were carried out by one and the same person (JP).

Table 2. Repeatability test with reference flour at two absorption levels. Volumes of loaves from four units of Panasonic 'home bakery'.a

\begin{tabular}{|c|c|c|c|c|}
\hline & \multicolumn{4}{|c|}{ 'home bakery' unit } \\
\hline & 1 & 2 & 3 & 4 \\
\hline \multicolumn{5}{|l|}{$\begin{array}{l}\text { Farinograph absorption } \\
\text { at } 500 \mathrm{~B} . \mathrm{U} \text {. consistency }\end{array}$} \\
\hline Loaf volume (mean) $n=4$ & $1218.9^{a}$ & $1300.0^{\mathrm{a}}$ & $1250.0^{\mathrm{a}}$ & $1300.0^{\mathrm{a}}$ \\
\hline Standard deviation & 80.0 & 54.0 & 54.0 & 20.4 \\
\hline Range & $1100-1275$ & $1224-1350$ & $1175-1299$ & $1275-1325$ \\
\hline \multicolumn{5}{|l|}{$\begin{array}{l}\text { Farinograph absorption } \\
\text { at } 500 \text { B.U. consistency } \\
\text { added with } 5 \text { percent units }\end{array}$} \\
\hline Loaf volume (mean) $n=4$ & $1687.5^{\mathrm{a}}$ & $1706.3^{\mathrm{a}}$ & $1681.3^{\mathrm{a}}$ & $1718.8^{\mathrm{a}}$ \\
\hline Standard deviation & 75.0 & 23.9 & 55.4 & 51.5 \\
\hline Range & $1600-1750$ & $1675-1725$ & $1600-1725$ & $1650-1775$ \\
\hline
\end{tabular}

a Mean followed by the same letter in rows showed no significant difference in Duncan's multiple range test at $\mathrm{P}=0.05$. 

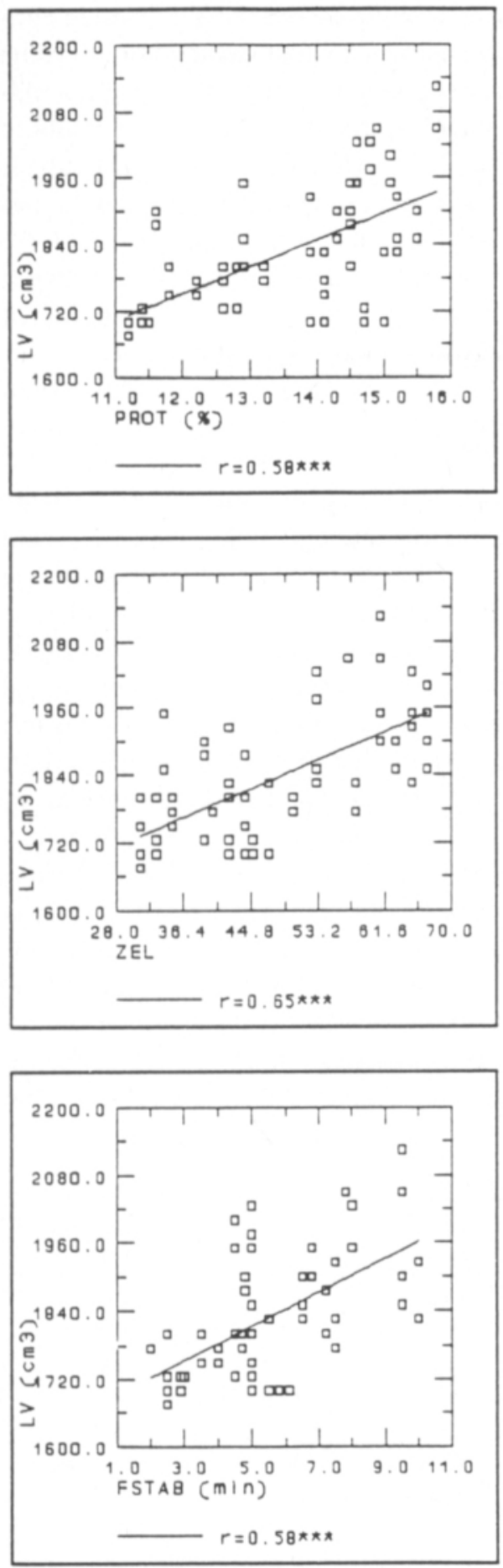

Fig. 1. Simple correlation coefficients between quality parameters and loaf volume in pooled data $(n=60)$. PROT $=$ protein content, WGLUT $=$ wet gluten content, $\mathrm{ZEL}=$ sedimentation value, FDDT $=$ farinograph dough developmental time, FSTAB = farinograph stability.
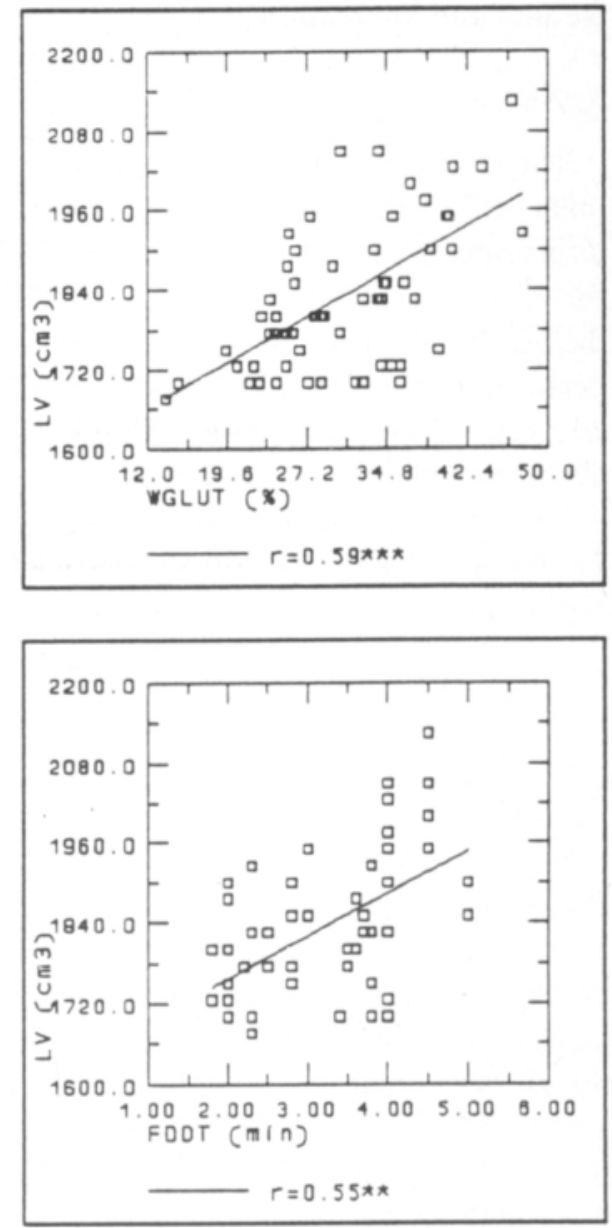

In preliminary tests performed with the commercial reference flour it was found that for optimal loaf volume and for optimal internal crumb characteristics farinograph absorptions equivalent to 5 per cent units higher than the standard farinograph absorption were required. This principle was subsequently applied in the baking tests with varietal flours, i.e. baking absorption was 5 percentage units higher than the farinograph absorption. The repeatability tests were made with regular white flour from a commercial flour mill (Vaasamills Ltd.), and the results were subjected to ANOva. Calculation of linear regressions were used to show response of loaf volume to quality parameters. 


\section{Results and Discussion}

\section{Repeatability}

The volumes of loaves made with the four units of Panasonic bread bakeries were similar irrespective of the baking unit with which the loaves were produced (Table 2). This indicates that the four units were equal in their performance and that no unit-specific differences affecting loaf volume existed. Higher absorption levels (farinograph absorption $+5 \%$ units) gave higher loaf volumes (Table 2). Irrespective of the absorption used the repeatability of the bakery units was good.

\section{Correlation with quality parameters}

Pooled data from all cultivars and all protein contents showed significant correlation of loaf volume to the quality parameters tested (Fig. 1). Loaf volume increased with increasing values of protein content, wet gluten content, sedimentation value, and farinograph dough development time and stability.

However, the varietal response to loaf volume with respect to quality parameters was not equal for all cultivars. The cultivars fell into two groups. Loaf volumes for three cultivars, Reno, Luja, and Ruso showed high sig- nificant positive correlations to protein content, wet gluten content, sedimentation value and farinograph development time and stability values. On the other hand, loaf volumes for the other three cultivars Kadett, Drabant and Tapio were independent of the same parameters (with only two exceptions) (Table 3 ).

In general, a strong correlation between protein content and loaf volume is considered to indicate good protein quality (see FINNEY and BARMORE (1948), and others). This would suggest that the protein quality in the three responsive cultivars (Reno, Luja, and Ruso) was higher than in the other three cultivars (Kadett, Drabant, and Tapio). However, there is no evidence of the reliability of the 'home bakery' baking procedure, i.e. whether it has any relevance with respect to industrial breadmaking processes. The automatic 'home bakeries' were not designed for test baking but rather for making bread of fairly consistent quality from commercial flours varying in quality. The technique and process were apparently designed to ensure good or reasonably good baking results in spite of variations in the quality of flour used, whereas a 'test bakery' should reveal differences. Therefore, it is questionable whether the present commercial 'home bakeries' are useful in test baking of flours of slightly different qualities. One

Table 3. Simple correlation coefficients between quality parameters and loaf volume in varietal data $(n=10)$.

\begin{tabular}{llllllc}
\hline Variety & Reno & Luja & Ruso & Kadett & Drabant & Tapio \\
\hline PROT & $0.92^{* * *}$ & $0.74^{* * *}$ & $0.79 * * *$ & $0.54^{\mathrm{ns}}$ & $0.50^{\mathrm{ns}}$ & $-0.11^{\mathrm{ns}}$ \\
Range & $11.4-15.8$ & $12.6-15.2$ & $11.2-15.5$ & $11.6-14.6$ & $12.9-15.1$ & $11.8-15.0$ \\
WGLUT & $0.89 * * *$ & $0.94^{* * *}$ & $0.74^{* * *}$ & $0.38^{\mathrm{ns}}$ & $0.34^{\mathrm{ns}}$ & $-0.06^{\mathrm{ns}}$ \\
Range & $21.9-40.3$ & $25.5-42.5$ & $14.3-37.7$ & $25.8-40.7$ & $26.8-38.8$ & $21.9-31.3$ \\
ZEL & $0.94^{* * *}$ & $0.76^{* * *}$ & $0.85^{* * *}$ & $0.73^{*}$ & $0.57_{\mathrm{ns}}$ & $-0.05^{\mathrm{ns}}$ \\
Range & $33-61$ & $40-65$ & $31-67$ & $39-65$ & $34-67$ & $31-47$ \\
FDDT & $0.94 * * *$ & $0.73^{*}$ & $0.82^{* *}$ & $0.59^{\mathrm{ns}}$ & $0.36^{\mathrm{ns}}$ & $-0.41^{\mathrm{ns}}$ \\
Range & $2.0-4.5$ & $2.2-3.8$ & $2.3-5.0$ & $2.0-4.0$ & $3.0-4.5$ & $2.0-4.0$ \\
FSTAB & $0.82^{* *}$ & $0.77^{* *}$ & $0.70^{*}$ & $0.92^{* * *}$ & $-0.44^{\mathrm{ns}}$ & $0.55^{\mathrm{ns}}$ \\
Range & $2.9-9.5$ & $2.0-10.0$ & $2.5-6.0$ & $4.8-8.0$ & $4.5-5.0$ & $3.5-5.5$ \\
\hline LV (mean) & $1877.4^{\mathrm{a}}$ & $1817.4^{\mathrm{a}}$ & $1772.4^{\mathrm{a}}$ & $1862.4^{\mathrm{a}}$ & $1880.1^{\mathrm{a}}$ & $1777.5^{\mathrm{a}}$ \\
Range & $1700-2087$ & $1763-1875$ & $1688-1875$ & $1725-1988$ & $1725-2000$ & $1763-1875$ \\
\hline
\end{tabular}

a cf. Figure 1.

b Mean followed by the same letter showed no significant difference in Duncan's multiple range test at $\mathrm{P}=0.05$. 
possibility for improving the procedure would be initially to mix the doughs in a farinograph mixing bowl and use the home-baking unit as a kneading/moulding and fermentation baking unit. However, the automatic nature of the process is then partly lost. This prelimi-

\section{References}

FinNeY, K.F. \& BARMORE, M.A. 1948. Loaf volume and protein content of hard winter and spring wheats. Cereal Chem. 25: 291-312.

SalovaArA, H. 1989. Typpilannoitustason ja proteiinipitoisuuden vaikutus kevătvehnälajikkeiden leivontalaadun tunnuslukuihin. (In Finnish). (Manuscript). Seibel, W. 1988. (Personal communication).

Svensson, G. \& Peltonen, J. 1991. New methods for nary study shows that more data are needed before definite conclusions can be made of the suitability of the home bakery for detecting varietal differences among comparatively similar types of bread wheat.

testing the baking quality of wheat varieties. Agri Hort. Gen. (In press).

Zawistowska U., Langstaff, J. \& Bushuk, W. 1988. Improving effect of a natural $\alpha$-amylase inhibitor on the baking quality of wheat flour containing malted barley flour. J. Cereal Sci. 8: 207-209.

Ms received June 18, 1990

\section{SELOSTUS}

\section{Kotileipurilaitteiden soveltuvuus vehnän koeleivontaan}

Jari Peltonen ja Hannu Salovaara
Tutkimuksessa selvitettiin neljăllă Panasonic (SDBT2P) kotileipurilla laitteen soveltuvuutta koeleivontaan. Koelajikkeina olivat kevătvehnät Reno, Luja, Ruso, Kadett, Drabant ja Tapio, joiden valkuaispitoisuus vaihteli $11-15 \%$. Tulokset osoittivat, ettă kotileipurilla saatiin toistettava leivontatulos. Leipătilavuus lisaaăntyi jauho- jen valkuaispitoisuuden, kostean sitkon mäărän, zeleny sedimentaatioluvun kasvaessa sekä farinogrammin tunnuslukujen parantuessa. Vehnälajikkeiden leivontatuloksissa oli eroja. Tutkimus kuitenkin osoitti, ettă lisătietoa tarvitaan leivontalaitteen kyvystä havaita pienehköjä eroja samantyyppisten lajikkeiden välillä. 